\title{
POSSIBILITIES OF THE APPLICATION OF THREE-DIMENSIONAL TECHNOLOGIES AND MODERN TECHNOLOGICAL MEANS IN THE CRIME INVESTIGATION ACTIVITY
}

\author{
Pavliuk N. V.
}

The issues related to the introduction of innovative methods, technologies and technological means in the investigation of crimes are considered. It is noted that one of the main directions of the development of Criminalistics is the assimilation of the virtual reality associated with computerization of spheres of life, implementation of modern technologies and their use in law enforcement. Technology use of laser scanning of terrain and objects resulting in $3 D$ model is produced allows several times to increase informative value of data collected at the incident scene, provides a visual and convenient visualization in three-dimensional form. As against photo and video images, 3D model has a stereoscopic image and the ability to freely change the angle while viewing. Besides to scanning results can be stored on any digital media without the possibility of changes or adjustments. Attention is focused on the technological capabilities of 3D-visualization systems on examples of their use in foreign countries as technological means of capturing the situation of the scene and the subsequent of a crime reconstruction. Thus, using a portable threedimensional imaging system for working with volumetric traces at a crime scene, it is possible to obtain accurate three-dimensional images of traces of protectors or footprints (shoes) on soil and snow. This system is an alternative to traditional methods of fixing evidence: photofixing and making plaster casts. Unlike other systems, new approach does not require the use of lasers. The expediency of expanding the range of $3 D$ laser scanning system use in modern investigative and judicial practice of our state with the aim of increasing the level of provision of pre-trial investigation authorities with technological means and bringing it closer to European standards is argued.

Keywords: crime prevention, laser scanners, $3 D$-visualization systems, crime pattern reconstruction, three-dimensional digital technologies, scene fixation.

DOI: https://doi.org/10.32353/khrife.2018.12

УДК 343.98:331.4

К. О. Спасенко, асистент кафедри криміналістики Національного юридичного університету імені Ярослава Мудрого, кандидат юридичних наук

E-mail:kafkrim1@gmail.com

\section{СЛІДОВА КАРТИНА ПОРУШЕНЬ ПРАВИЛ БЕЗПЕКИ ПІД ЧАС ВИКОНАННЯ РОБІТ ІЗ ПІДВИЩЕНОЮ НЕБЕЗПЕКОЮ}

Розглянуто позииії та підходи науковичів до визначення типових слідів порушення правил безпеки під час виконання робіт із підвищеною небезпекою. Констатовано, щьо матеріальні сліди порушення правил безпеки при виконанні робіт із підвищеною небезпекою виявляються як безпосередньо на місиі подї, так $і$ в різних документах. Запропоновано до числа типових матеріальних слідів віднести: сліди-ушкодження на тілі потерпілого; сліди

(C) Спасенко К. О., 2018 
рук, ніг, мікрочастинки одягу потерпілого або злочиния; сліди руйнування споруди, машин або механізмів тощзо.

Ключові слова: криміналістична характеристика; елементи криміналістичної характеристики, порушення правил безпеки під час виконання робіт із підвищеною небезпекою, типові сліди злочину.

Ураховуючи специфіку порушення правил безпеки при виконанні робіт із підвищеною небезпекою, слід зазначити, що особливе місце в криміналістичній характеристиці цього злочину займають типові сліди. Типові сліди злочину на місці події надають важливу інформацію про умови, у яких здійснюються зазначені роботи, певні небезпечні чинники, технічні причини порушення тощо. Тому дослідження цього елемента криміналістичної характеристики видається доцільним і необхідним.

У науковій літературі проблематиці з дослідження елементів криміналістичної характеристики присвятили праці такі науковці, як Р. С. Бєлкін, В. А. Журавель, В. О. Коновалова, І. О. Кучерков, В. В. Тіщенко, В. Ю. Шепітько, М. П. Яблоков та ін.

Як слушно зазначає I. О. Кучерков, порушення правил безпеки знаходять своє матеріальне відображення в специфічній обстановці, яка становить собою сукупність матеріальних слідів події, що дозволяють установити факт порушення будівельних правил, винних осіб, інші обставини події. Ці сліди можуть перебувати як безпосередньо на місці події, так і відображуватися в різних документах, пов'язаних із виконанням робіт. Сліди на місці події можуть надати інформацію про умови, у яких проводилися ці роботи, про наявність небезпечних виробничих і зовнішніх чинників, про технічні причини події, про ступінь вини потерпілого в ній. На підставі цих даних слідчий може скласти приблизну картину події й висунути основні версії про іiі механізм, про наявність або відсутність порушень з боку конкретних посадових осіб'.

Слід зазначити, що до матеріальних слідів порушення правил безпеки в процесі виконання робіт із підвищеною небезпекою необхідно відносити, передусім, результати відбиття злочинної діяльності в матеріальному середовищі ${ }^{2}$. Вид і характер порушення правил безпеки впливає на особливості формування типових слідів порушення правил безпеки під час виконання робіт із підвищеною небезпекою, до числа яких можна віднести такі:

- сліди-ушкодження на тілі потерпілого у вигляді синців, садин, ран, розірваного одягу потерпілого, гематом на обличчі, шиї, руках, стегнах тощо;

- сліди рук, ніг, мікрочастинок одягу потерпілого або злочинця-порушника (наприклад, у випадку їх спільного знаходження на одному будівельному майданчику);

Кучерков И. А. Расследование преступных нарушений правил безопасности при проведении строительных работ : дис. ... канд. юрид. наук : 12.00.09. Москва, 2003. С. 54.

Кримінальний кодекс України: наук.-практ. коментар / Ю. В. Баулін, В. І. Борисов, С. Б. Гавриш та ін. ; за заг. ред. В. В. Сташиса, В. Я. Тація. Вид. 4-те, доп. Харків : Одіссей, 2008. С. 436. 
- сліди руйнування важливої для виробництва споруди, машин або механізмів чи руйнування жилої будівлі.

Отже, до матеріальних слідів злочинної діяльності в матеріальному середовищі, що настали в результаті дії або бездіяльності, пов'язаної з порушенням правил безпеки виробництва, слід віднести наявність трупів, тілесних ушкоджень у потерпілих, сліди руйнування чи пошкодження приміщень, обладнання ${ }^{1}$.

Крім цього підкреслимо, що при нанесенні тілесних ушкоджень або настанні смерті у зв'язку з виконанням робіт із підвищеною небезпекою поруч із зазначеними матеріальними слідами, які можуть залишатися на потерпілому, існує реальна можливість виникнення їх і на об'єктах обстановки місця події (цех, склад, будівельний майданчик, шахта), при контактуванні потерпілого з ним (краплі крові, частини засобів індивідуального захисту та ін.).

При цьому важливим є той факт, що вид і загальна характеристика типових матеріальних слідів у вигляді нанесення певних тілесних ушкоджень потерпілому знаходяться у прямій залежності від фактичного виду робіт, під час яких стався нещасний випадок. Адже, наприклад, при виконанні слюсарних робіт за допомогою машин і механізмів, на яких $є$ обертальні, ріжучі частини пристрою, можлива наявність слідів у виді розрубу, розпилу, розрізу чи розриву на тілі потерпілого, утворення яких пов'язано 3 дією машин і механізмів, на яких виконувалися ці роботи. Так, начальник борошномельного виробництва ТОВ КПФ «Рома» 14 грудня 2012 р. допустив до роботи старшого апаратника борошномельного виробництва Л., кваліфікація якого не відповідала роботі з підвищеною небезпекою на вальцевих верстатах, свідомо знаючи, що той не пройшов спеціального навчання і не здав іспитів, дозволивши йому виконувати обов'язки з помолу зерна. Крім того, К., будучи керівником робіт із підвищеною небезпекою, недобросовісно виконуючи свої службові обов'язки, порушив п. 4.10 посадової інструкції і не здійснив контролю за дотриманням правил і норм охорони праці, правил поводження з машинами, механізмами, устаткуванням підлеглим йому працівником, унаслідок чого Л., не будучи навченим безпечним умовам праці при виконанні робіт із підвищеною небезпекою, порушуючи п. 1.10 Інструкції апаратника, затвердженої 3 січня 2012 р. виконавчим директором, відкрив захисну огорожу, не відключивши при цьому верстат від живлення, і почав руками прибирати з вальців залишки продуктів помолу. Під час прибирання навантаження на вальці зменшилося, і верстат запустився, при цьому затягнувши пальці лівої руки Л. між валками, унаслідок чого потерпілий отримав тілесні ушкодження у виді травматичної ампутації 2, 3, 4 і 5-го пальців лівої кисті на рівні п'ясткових кісток і 1-го пальця лівої кисті на рівні основної фаланги, які згідно 3 висновками судово-медичної експертизи № 152-ПР/12 від 12 червня 2012 р. належать до тяжких тілесних ушкоджень. Отже, К. як службова особа до-

\footnotetext{
${ }^{1}$ Волобуєв А. Ф. Криміналістика : навч. посіб. Київ : КНТ, 2011. С. 436.
} 
пустив низку порушень нормативних документів з охорони праці й техніки безпеки, що спричинило за собою тяжкі наслідки ${ }^{1}$.

Треба звернути увагу, що носіями матеріальних слідів також слугують деякі документи, пов’язані з організацією безпеки виробництва на підприємстві, ділянці, під час виконання певного виду робіт. Документ являє собою матеріальний носій інформації, призначений для іiі передачі в часі та просторі ${ }^{2}$. Носіями відомостей про порушення правил безпеки можуть бути такі документи. По-перше, документація про організацію безпечного виконання робіт (до вчинення правопорушення):

— статут і колективний договір підприємства;

— накази й розпорядження про створення організаційного підрозділу 3 питань охорони праці та проведення профілактичних заходів 3 охорони праці;

— накази про прийняття на роботу працівників і про покладення на них обов'язків із дотримання правил безпеки;

— посадові інструкції, положення та інструкції з техніки безпеки;

- акти про проведення атестації робочих місць;

- медичні картки працівників і документація щодо проведення медичного огляду працівників;

— договори й первинна документація щодо проведення навчання та щорічної перевірки знань із питань охорони праці;

- розпорядження щодо проведення інструментального контролю машин та журнали обліку їх технічного стану й техніки безпеки;

- журнали розпоряджень по дільниці;

— посвідчення й ліцензії, що дають право на проведення робіт.

По-друге, документація про організацію безпечних робіт безпосередньо при їх виконанні:

- наряди-допуски на виконання робіт (у тому числі передбачені спеціальними нормативно-правовими актами);

- журнали прийому та здавання вантажопідіймальних машин і механізмів;

- журнали видачі змінних завдань;

- журнали обліку вступного інструктажу з техніки безпеки та 3 охорони праці;

- журнали реєстрації інструктажів із питань охорони праці працівників;

— документи, що містять відомості про видачу засобів індивідуального захисту;

— акти про проведення попередньої перевірки машин і механізмів, на яких виконуються роботи з підвищеною небезпекою;

- транспортні листи щодо перевезення захисних огорож із певного місця з метою їх установлення.

\footnotetext{
1 Архів Первомайського міськрайонного суду Харківської області за 2012 р., спр. № 1/2030/240/12.

2 Криміналістика: академічний курс : підручник / Т. В. Варфоломеєва [та ін.]. Київ : Юрінком Інтер, 2011. С. 165.
} 
По-третє, документація, що була складена після порушення правил безпеки:

- повідомлення про нещасний випадок на підприємстві, в установі чи організації;

- акт проведення розслідування (спеціального розслідування) нещасного випадку (аварії), що стався (сталася) (форма Н-5);

- акт про нещасний випадок, пов'язаний з виробництвом (форма Н-1);

— картка професійного захворювання (отруєння) (форма П-5);

- журнал реєстрації осіб, які потерпіли від нещасних випадків на виробництві;

— висновок про аварію, катастрофу, пригоду (подію) на транспорті, що сталася (форма Т-1);

- припис уповноваженого органу про усунення причин настання небезпечних наслідків (форма Н-9);

- протокол огляду місця, де стався нещасний випадок ${ }^{1}$.

Також слід звернути увагу, що на характер слідів у зазначеній організаційній документації щодо порушення правил безпеки під час виконання робіт із підвищеною небезпекою, на їх наявність або відсутність впливає специфіка способу (форми) порушення цих правил. У разі їх порушення шляхом невидачі засобів індивідуального захисту слідами будуть відомості, що містяться в документах, про їх видачу. У випадку порушення вимог при вантажно-розвантажувальних роботах за допомогою машин і механізмів слідами будуть відомості, що містяться в документах про проведення інструментального технічного їх огляду й контролю за справністю, відомості в транспортних листах.

Характер документації, у якій містяться відомості про дотримання правил безпеки, залежить від специфіки виконуваних робіт. Зокрема, на думку В. М. Махова зі співавторами, до документів, що містять важливу інформацію про виконання будівельних робіт на висоті, що потягло за собою падіння потерпілого, слід віднести: паспорт на інвентарні ліси, підмостки, колиски; письмовий дозвіл головного інженера будівництва на виготовлення та експлуатацію неінвентарних лісів; проект споруди неінвентарних лісів; акт приймання риштувань і помосту виробником робіт; акт приймання лісів комісією; повторний акт приймання лісів при поновленні робіт; акт випробування підвісних, підйомних лісів і колисок; акт випробування гачків для підвіски лісів; акт випробування приставних сходів; акт випробування запобіжних поясів і документи на їх надходження й видачу робочим; документи, що свідчать про стан погоди в момент події; документи, що свідчать про наявність у робітника права працювати на висоті².

Виділення матеріальних слідів тісно пов'язано з обстановкою вчинення злочину, зокрема, з часом, місцем, видом виробництва, характером викону-

1 Спасенко К. О. Документообіг і його значення при розслідуванні порушень правил безпеки під час виконання робіт із підвищеною небезпекою. Теорія та практика судової експертизи і криміналстики. 2015. Вип. 15. С. 135-136.

2 Махов В. Н., Образцов В. А., Чернова К. Т. Расследование преступных нарушений правил при производстве строительных работ. Москва : ВНИИПП, 1979. С. 83. 
ваних робіт. Ці сліди можуть свідчити про певні обставини вчинення злочину, а саме про: а) характер події, умови роботи (висока або надто низька температура, вогкість повітря, безлад на робочих місцях, значна концентрація пилу або отруйних речовин, слабка освітленість); б) неробочий стан механізмів, пристосувань та інструментів, якими користувався потерпілий; в) причину події (несправність верстатів і механізмів, контрольних, вимірювальних і сигнальних приладів, оплавлення дротів, що свідчить про коротке замикання, відсутність засобів індивідуального захисту тощо) ${ }^{1}$.

Винні особи, усвідомлюючи, що сліди можуть сприяти викриттю їх причетності до вчинення розглядуваних злочинів, часто докладають зусилля, спрямовані на їх знищення або спотворення, наприклад, можуть бути списані й демонтовані механізми, при експлуатації яких стався нещасний випадок; до прибуття працівників правоохоронних органів не припиняються роботи на ділянці, де сталася подія; уносяться зміни в документи, пов'язані 3 охороною праці в організації, або, якщо документ занадто компрометує посадових осіб, - зовсім знищується та ін. Тим самим розслідування такого злочину значно ускладнюється, унаслідок чого кримінальне провадження може бути закритоㅇ.

Таким чином, можна підсумувати, що типові сліди порушення правил безпеки під час виконання робіт із підвищеною небезпекою детерміновані видом виконуваної роботи, способом (формою) порушення правил безпеки, обстановкою й місцем.

\section{СЛЕДОВАЯ КАРТИНА НАРУШЕНИЙ ПРАВИЛ БЕЗОПАСНОСТИ ВО ВРЕМЯ ВЫПОЛНЕНИЯ РАБОТ С ПОВЫШЕННОЙ ОПАСНОСТЬЮ}

\section{Спасенко К. $А$.}

Рассмотрены позищии и подходы ученых к определению типичных следов нарушения правил безопасности во время выполнения работ с повышенной опасностью. Констатировано, что материальные следы нарушения правил безопасности при выполнении работ с повышенной опасностью выявляются как непосредственно на месте происшествия, так и в различных документах. Следын на месте события могут предоставлять информацию об условиях, в которых осуществляются эти работы, о наличии опасных производственных и внешних факторов, технических причинах нарушения, степени вины пострадавтего и т. $n$. K числу типичных материальных следов принадлежат: повреждения на теле пострадавшего; следы рук, ног, микрочастицы одежды пострадавщего или преступника-нарушителя; разрушение важного для производства сооружения, машин или механизмов или жилого здания. Выделение материальных следов тесно связано с обстановкой совершения преступления, в частности, со временем, местом, видом производства, характером выполняемых работ. Эти следы могут свидетельствовать об определенных обстоятельствах совершения преступления, а именно о:

Волобуєв А. Ф. Зазнач. твір. С. 437.

2 Кучерков И. А. Зазнач. твір. С. 55. 
характере события, условиях работы; нерабочее состояние механизмов, приспособлений и инструментов, которыми пользовался пострадавший; причине события. Носителями материальных следов также являются определенные документы, связанные с организацией безопасности производства на предприятии, участке во время выполнения определенного вида работ. Каждый вид (группа) преступлений отличается наличием определенной «следовой картины», обобщенные данные о которой имеют существенное практическое значение для их расследования. Совокупность данных о материальных следах преступления, их особенности и локализачию необходимо рассматривать как один из элементов криминалистической характеристики преступлений, касающихся нарущения правил безопасности при выполнении работ с повышенной опасностью.

Ключевые слова: криминалистическая характеристика, элементы криминалистической характеристики, нарушение правил безопасности во время выполнения работ с повышенной опасностью, типичные следы преступления.

\section{TRACE PATTERN OF SECURITY LAPSE WHILE INCREASED DANGER WORKS}

Spasenko K. $\boldsymbol{O}$.

Positions and approaches of scientists to determine the typical traces of violation of safety rules during performance of increased danger works are considered. It was stated that material traces of violations of safety rules during performance of increased danger works are detected as directly on the scene as in various documents. Trace on the scene can provide information on the conditions under which these works are carried out, the presence of dangerous manufacturing and external factors, technical causes of violation, degree of victim's fault, etc. Typical material traces include victim's body damage; traces of hands, feet, microparticles of the victim or offender clothes; destruction of important building for production, of mechanisms or machinery or of residential building. Allocation of material tracks is closely linked to the situation of crime commission, in particular, to time, place, type of production, nature of performed work. These traces can indicate certain circumstances of crime commission, namely: event nature, work conditions; inactive status of mechanisms, devices and tools used by the victim; event cause. Material traces bearers are certain documents related to the workplace safety management at enterprise, on site during execution of a particular type of works. Each type (group) of crimes is characterized by the availability of a certain Trace Patterns which generalized data are essential practical importance for their investigation. Data set on material traces of a crime, their features and localization should be considered as one of elements of criminalistic description of the crimes regarding violation of safety rules during increased danger works.

Keywords: criminalistic description, elements of criminalistic description, violation of safety rules during increased danger works, typical traces of a crime. 